REVISTA ARA N7 . VOLUME 7 . PRIMAVERA+VERÃO 2019 • GRUPO MUSEU/PATRIMÔNIO FAU-USP

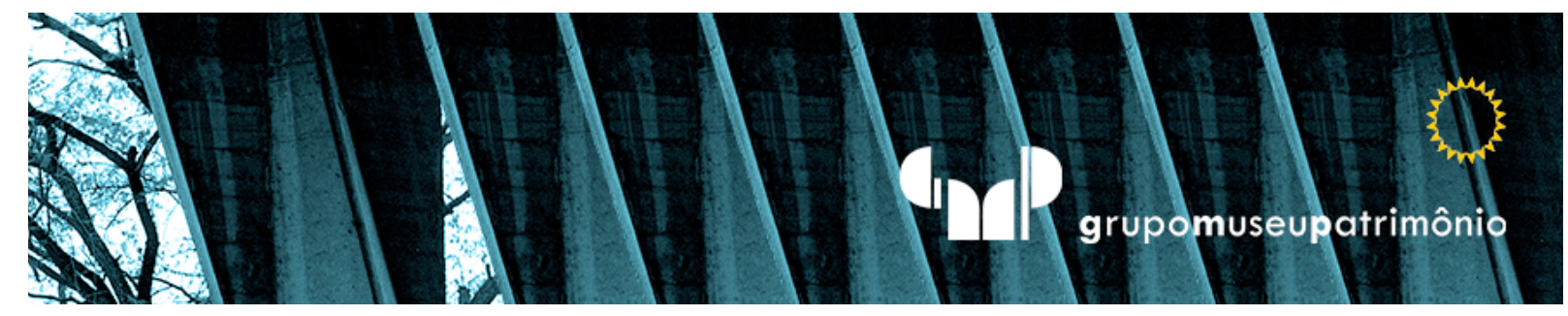

\title{
Memorial: \\ limiar entre rito e conflito
}

\author{
Memorial: umbral entre rito y conflicto
}

\section{Memorial: threshold between rite and conflict}

Maria Cecília França Lourenço

Professora Titular Sênior. Faculdade de Arquitetura e Urbanismo/FAU, Universidade de São Paulo/USP, São Paulo, BR

mcfloure@usp.br 


\title{
Resumo
}

O estudo aborda memoriais, em embate com fatos em curso, a causar reações extremas. A avaliação de aspectos influentes e outros visa discutir se inseri-los tenderia a eternizar histórias prestes a se desfazer, seja de pessoas, grupos ou causas, que sofrem pacto de silêncio. Ressalte-se que parte da análise aqui exposta foi assinada por Oscar Niemeyer, cuja coesão em ideais e criação está fixada na cultura mundial. Ainda assim, originam conflitos.

Palavras-Chave: Memorial. Espaço. Patrimônio. Luto. Lembranças concorrentes.

\section{Resumen}

El estudio discute los monumentos, en enfrentamiento con hechos actuales, provocando reacciones extremas. La evaluación de aspectos influyentes y otros discuten si insertarlos tienden a perpetuar historias a punto de deshacerse de las personas, grupos o causas, sufren el Pacto de silencio. Destacar que parte del análisis aquí expuesto ha sido firmado por Oscar Niemeyer, cuya cohesión ideal y creación se encuentra en el mundo de la cultura. Sin embargo, causar conflictos.

Palavras-Clave: Memorial. Espacio. Patrimonio. Luto. Memorias que compiten.

\begin{abstract}
The study discusses memorials, in clash with ongoing facts, causing extreme. The evaluation of influential aspects and others discuss whether inserting them would tend to perpetuate stories about to get rid of any persons, groups or causes, suffering Pact of silence. Highlight that Oscar Niemeyer, whose ideal cohesion, has signed part of the analysis here exposed and creation is set on world culture. Still, cause conflicts.
\end{abstract}

Keywords: Memorial. Space. Heritage. Mourning. Competing memories. 


\section{INTRODUÇÃO}

Em uma teoria do tempo, todos os conflitos, compromissos e formações de consenso podem ser atribuídos a tensões $e$ rupturas - não há como escapar das metáforas espaciais - [...]. Reinhart Koselleck, (2014, p. 9-10)

para reminiscências. Apoiadores desafiam o tempo e sonham em perpetuar valores, prestes a se dissipar. Investigar o conjunto, a abranger edifício e reações, pode elucidar interdito e tensão, que desvelam causas e intentos. Ainda que haja decorrido longo tempo, emergem questões, que, para se firmar, fundam-se em narrativas, no limiar entre posições antagônicas e lembranças concorrentes a se confrontar.

Memorial se afere já na Antiguidade grega, como afirma Aleida Assmann em pesquisa essencial atinente aos lugares em que se fixam lembranças, cujo título é Espaços da recordação (2011). Assinala a existência de longa duração do termo, pois, na peça do poeta Eurípides, Ifigênia em Aulis, esta menciona o desejo se eternizar, ao partir para a Guerra de Tróia. Registra na citada tragédia: “Não terei uma sepultura, mas sim um memorial!” (2011, p. 47). 
Trauma, conflito, embate e guerra suscitam implante público de formas capazes de, por um lado, homenagear, de outro, desafiar, garantir fama e duração de dada crítica, que se deseja preservar ou desnudar. Encontram-se em espaços que constituem umbral denso entre passado doloroso, presente diverso e aspirações futuras. Agenciam-se, além destes fatores regidos por Cronos, outros, como identidade, heroismo, raridade, espírito público para cravar na história passagens, datas cívicas ou adjetiva-se com senso oposto.

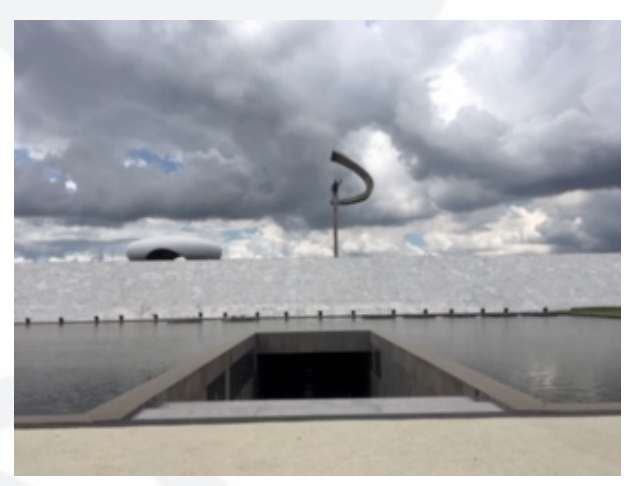

Figura 1. Oscar Niemeyer. Memorial JK. Brasília/DF. Foto A. 18.04.2019

Selecionei aqui memoriais ${ }^{1}$, que mais resvalam no limiar entre vida e morte, fixados em formas artísticas, que desnudam a latência entre lutas de ontem e absurdos no presente. Emergem porões e embates, por vezes submersos em eras distantes. No país desde que se propagou Anistia $(1979)^{2}$ até a aurora do frágil liame democrático, marco ansiando pelo final da última Ditadura civilmilitar (1964-85), vozes exigiam que fosse ampla e irrestrita, um modo para evitar amnésia sobre vítimas e banidos. Estes agiram contra censura, farsa eleitoral, elo entre poder econômico, civil, militar e engodo entre fala e sigilo.

\footnotetext{
${ }^{1}$ Pesquisa desenvolvida junto ao Grupo Museu Patrimônio como parte do projeto de Professor Sênior FAU USP

${ }^{2} \mathrm{O}$ último presidente na Ditadura, João Batista de Figueiredo, remeteu após 3 meses da posse Decreto de Anistia ao Congresso e a rapidez aponta a hipótese de que já estivesse elaborado. Assinale-se que, desde 1974, familiares e ativistas atuavam para dirimir farsas em discursos.
} 
Assmann aduz à mudança do papel em memoriais, na condição de memoriais estabilizadores (2011, p. 53), para órgão de raio político, o que se afere em parcela destes em exame. Assim quanto mais "[...] crítica uma época e quanto mais avassaladora a autoconfiança dos diferentes grupos de interesses, tanto mais numerosos e teatrais se revelaram [...]" (idem). Adiciona que se voltam então por muitas maneiras "[...] ao desejo de eternizar o presente e de negar o processo histórico" (idem). Ressalva além disso outros por ela chamados de memoriais revolucionários, afeitos a causas emergentes e essenciais.

Nesse cenário, ações para dedicar Memorial a avessos ao Golpe gerou e segue causando reações. Cada conflito desvela estratégias para banir, exilar, prender e aviltar o humano. Neste estudo, a análise de tais atos abarca alguns, em outros países e, neste, em três cidades: a capital do país, palco dos militares no período ditatorial, São Paulo, um dos pioneiros em propor memorial e tombamento; e Porto Alegre, terra de Luis Carlos Prestes.

O Memorial Prestes situa-se em área adensada de Porto Alegre e gerou reações, ante seu ativismo contra regalias. Até ser aberto, após 21 anos, foi alvo de protestos ${ }^{3}$ : lança-se a pedra inicial em 1998 e, com mutações políticas, virá a público apenas em 2017. Em que pesem ensaios para consolidá-lo, apenas viabilizou-se com auxílio da Federação Gaúcha de Futebol, que financiou e recebeu parte do terreno, na gestão do Partido dos Trabalhadores.

Atente-se ser esta a primeira obra notável do arquiteto na cidade, que doa o projeto, em parceria com seu bisneto Paulo. Em carta mantida no Memorial, assevera Niemeyer que visava a "[...] manter viva a memória de Prestes, um brasileiro que lutou em favor de seu povo, contra a miséria e a desigualdade social que, infelizmente, ainda persistem em nosso país". Não se trata de exceção, uma vez que outro projeto para Porto Alegre, doado pelo arquiteto,

${ }^{3}$ Em 2004, informava-se a presença de faixas, flores em atos de repúdio, sob o pretexto de utilização de verba pública. Em 2017, jornais locais informaram que Lei Complementar tramitava para mudar o uso, dito atrasado, para Museu Histórico da Cultura Negra, digno, mas, desviante do que antes se propora. Em 2019, funciona com ressalvas, dado o descaso das autoridades. 
aguarda aval: "Caminho da Soberania", dedicado a João Goulart, Getúlio Vargas e Leonel Brisola, indicando conflitos ainda polarizados.

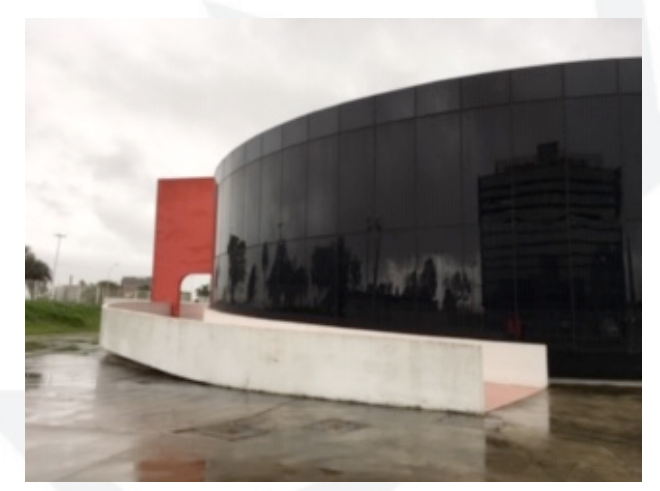

Figura 2. Arq. Oscar Niemeyer. Memorial Luís Carlos Prestes. Porto Alegre/RS. Foto A. 31.05.19

Memoriais com menção a período obscuro têm atraído notável espectro de arquitetos, a denunciar dobras sutis no trato público. Assim, convidou-se figuras como João Filgueiras Lima, o Lelé, a criar o Memorial Darcy Ribeiro ${ }^{4}$, na Universidade de Brasília/UnB, em que fôra o primeiro reitor. E Niemeyer, além do dedicado a Prestes, projetou dois outros: o do ex-presidente Juscelino Kubitschek e o dos Povos Indígenas, à sua frente, na Praça Buriti, aberto em 1987, logo no que se combinou chamar "Abertura Democrática".

Repetição e renovação de narrativas reafirmam indignação e desejos de duração, em certa fração social e histórica. Em geral, as soluções espaciais residem nas excepcionais, para cumprir papel na celebração de vida e coesão em ideais. Todavia, estilo e atributos de quem cria também se repetem e cumprem expectativas. Ademais, o tempo pode desgastá-las, quando vigoram posições diversas, em comparação ao projeto inicial, testemunho de outra era.

\footnotetext{
${ }^{4}$ Ribeiro foi antropólogo, educador, escritor, político, com cargos de ponta em governos anteriores ao Golpe, a saber, Ministro da Educação (J. Quadros) e Chefe da Casa Civíl (J. Goulart).
} 


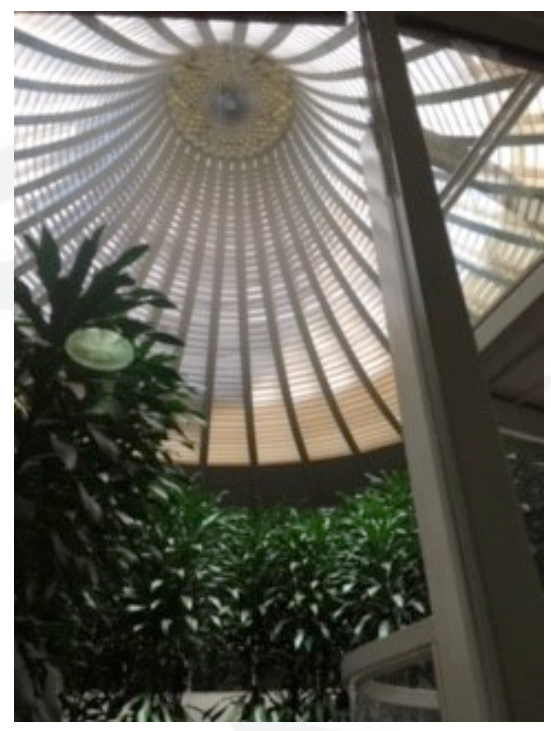

Figura 3. Arq. Joaquim Filgueira. Memorial Darcy Ribeiro, conhecido como Beijódromo. Brasília/DF. Foto A. 01.05.2019

\section{Sonhos e pesadelos}

[...] Narrativa e construção operam um mesmo tipo de inscrição, uma na duração, a outra na dureza do material. Cada novo edifício inscreve-se no espaço urbano como uma narrativa em um meio de intertextualidade [...].

Paul Ricoeur (2007, p.159).

Projeto que leve a refletir e manter partes do vivido causará ou não fruição e novas atitudes, ainda que edifícios, coleções e exposições surpreendam pela concepção. Sonha-se com adesão por público variado, apoio com verbas e pessoal, advindos do poder. Concepções tentam comover partes envolvidas, da família às múltiplas faixas etárias e societárias, pelo uso de pressupostos plurais, concepção crítica, diálogo com questões conflituosas na cultura contemporânea e releitura revigorada para humaizar o que se memorializa.

Defende-se aqui, que não se afere cultura por cifras ou números, nem sempre fiéis, mas há que se avaliar criação de algo incomum, ativo e pulsante, que induz decisão eletiva do espectador para voltar. Seja em Brasília ou em outras partes, vicejam defensáveis esforços multidisciplinares, a reunir arquiteto, 
museólogo, designer, educador, historiador e especialista da área, para levar adiante ações consequentes a inúmeras gerações, como se espera no trato da memória. No entanto, como prover verbas sem mercantilizar aquilo que se celebra, ou autoria no projeto e reduzi-la a mero espetáculo etéreo?

A par de motivar sonhos, memoriais deflagram pesadelo em vários momentos, repõem interdito e silêncios. Estes advêm de rusgas, oposição, crença, punição, destruição do legado efetivo ou até furto material quando abriga tesouro. Atente-se como o Memorial JK elucida ações da chefia do país ${ }^{5}$, por ser proposto em plena Ditadura, após a morte trágica deste, em $1976^{6}$. O projeto inscrevia-se no espaço como um manifesto, não apenas a JK, mas, libelo contrário aos atos de caça a cidadãos e cassação de direitos políticos.

Ato primeiro se deu, na forçosa lei de Luto Oficial, dada a comoção causada. Afinal, negar seria valorizar JK, pois, poderia resultar em revolta. A solução armada reduziu-se a impedir cada etapa, sinalizando que seria imperativo interpor barreiras ao proposto. Procuram então fronteiras a desafiar conflitos, negociadas passo a passo, gerando o que Asmann nomeia "memorial estabilizador" (2011, p. 53), espaço no limiar entre contendas.

Kubitscheck, Presidente da República entre 1956-61, morreu em mais uma fase nebulosa do Golpe 7 . Some-se crise geral na economia advinda do Petróleo (1974), associada à queda de índices nacionais. Não se citavam mais megaobras em várias áreas, como a Rodovia Transamazônica ${ }^{8}$, cujo bordão era

\footnotetext{
${ }^{5}$ Entre $1974-9$ o Estado esteve sob o comando do General Ernesto Geisel.

${ }^{6} \mathrm{JK}$ faleceu em acidente de carro, com seu motorista Geraldo Ribeiro, em 1976. Velado na Catedral, levado em carro de bombeiros e séquito, ao final, o caixão foi retirado por populares, que o conduziram ao Cemitério Campo da Esperança. Entoavam cantigas e Hino Nacional, sendo enterrado na Praça dos Pioneiros, dado o renome obtido, por certo, a incomodar o sistema.

${ }^{7}$ Informes são controversas, pois, entre 2013 e 2014, o Estado brasileiro formulou decisões em conflito sobre as causas da morte entre a Comissão Municipal da Verdade /CMV paulistana e a respectiva Nacional. A primeira registrou que a morte decorreu de "assassinato pelo regime militar", enquanto para a outra, em relatório inicial, "afirmou ter havido acidente".

${ }^{8}$ Pretendia ligar Norte e Nordeste do país ao Peru, com, mais de 5.500 km de extensão e para tanto dizimou povos indígenas e extensa mata. Iniciada em 1969, mantém-se em grande parte em terra e na época de chuvas fica intransitável, dados estes apenas divulgados após 1985, a reclamar por perícia sobre destino e uso de fundos públicos.
} 
“Integrar para não entregar". A via até 2019 apresenta-se em nível precário e, já à época, entraves não resolvidos abalam a fábula sobre o tal milagre brasileiro. Muito colaborou para a ilusão, crédito internacional a juros deletérios. Enfim dissipava-se o bordão, "Ninguém segura este país".

Kubitscheck elegera-se Senador por Goiás, mas com o Golpe tivera direitos políticos suspensos e perdera este mandato (08.06.1964). Nesse quadro, talvez o poder julgasse mais apropriado sepultar a imagem de sonhador que, com o lema "50 Anos em 5", convocara arquitetos de proa para erguer a nova capital e artistas confluindo no projeto. Teria chances de se eleger presidente, ainda que houvesse decorrido dez anos de afastamento e caso tivvesse eleição.

JK exilara-se por três anos e arriascara voltar com a morte da irmã, período aquele em que tentam por discurso, não comprovado, difamá-lo ante o cidadão. Na vigência da ditadura, alegava-se que fôra afastado por roubo ao construir Brasília. Insistia-se em apregoar, em plena Guerra Fria, que se aliara a comunista, na consagrada prática de desqualificar para eliminar. Com censura instalada, talvez espelhassem a própria prática em curso.

O comunista aludido seria Niemeyer, que se exilara logo após o Golpe e lá ascendera a notória posição ${ }^{9}$. Tudo conspirava para não se aprovar a construção do Memorial JK. Melhor para os militares seria remetê-lo ao ostracismo, ainda que o espaço de recordação fosse projetado pelo expressivo arquiteto. Agrava esse quadro o desatino do poder, uma vez que, no final de 1975 e no seguinte, efetivaram-se inúmeros atentados ${ }^{10}$.

\footnotetext{
${ }^{9}$ Ressaltem-se obras fora do país até os Anos 1960: concurso e com Le Corbusier, para Sede da ONU (EUA); Universidade de Haifa (Israel), a de Ciência e Tecnologia Houari Boumediene e a de Constantina ambas na Argélia. Sede da Editora Mondadori (Itália). Recebeu Prêmio Lênin da Paz, Exposição no Museu de Artes Decorativas/ Paris, Medalha Juliot Curie e o Grande Prêmio Internacional da Arquitetura e de Arte, da revista L'Architecture d'Aujourd'hui.

${ }^{10}$ Morrem: Chefe de Jornalismo da TV Cultura/ SP, Vladimir Herzog; metalúrgico Manoel Fialho Filho no Departamento Estadual de Ordem Política e Social/ SP; estilista Zuzu Angel que denunciara o sumiço de seu filho nos EUA e sofre em acidente de carro/RJ; ataque a bomba na Associação Brasileira de Imprensa/ RJ e outro, desativado na Ordem dos Advogados do Brasil/ RJ; e similar, ao jornal Opinião; sequestrado bispo de Nova Iguaçu, D. Adriano Hypólito.
} 
Nesse ambiente repressivo ${ }^{11}$, como aprovar o Memorial, que o recolocaria na História, como chefe eleito, popular, criador de Brasília? Adiam o tributo ao militar, médico e presidente. Sarah, viúva de JK, obtivera adesão de Adolpho Bloch, dono de mídia de amplo alcance na época, ou seja, Revista Manchete e rede de TV, e prepararam base popular com a campanha "Você constrói o Memorial JK", decisiva para superar percalços.

Sob o comando de João Babtista Figueiredo, efetiva-se abertura do Memorial JK, com a presença de Figueiredo, em 1981, na data de nascimento do homenageado (12.9). Nesse cenário funesto, Niemeyer cria paredes curvas, como se o visitante entrasse no túnel de outro tempo luminoso, circundado por espelho d'água e rampa de acesso. Depara-se com formas brilhantes, em displays iluminados, predomínio prateado e reservando dourado para objetosrelíquias; de outro, o conjunto marca o início da tal distenção política.

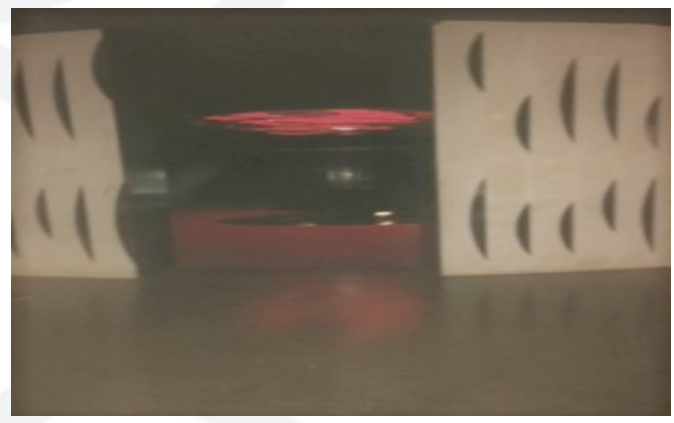

Figura 4. Arq. Oscar Niemeyer. Memorial JK. Brasília/DF. Painel de Athos Bulcão e vitral de Marianne Peretti. Foto A. 18.04.2019

O conceito de Síntese das Artes modernista raia com brilho: reúnem retrato criado por Cândido Portinari, painéis de Athos Bulcão como os da entrada do túmulo, vitral sob luz externa natural sobre câmara mortuária, de Marianne Peretti, jardim lateral à Biblioteca de Roberto Burle Marx, toque popular -

\footnotetext{
${ }^{11}$ Encerra-se 1976 com outras indignações: morte de João Goulart, atribuída à natural; e, "Chacina da Lapa" /SP, em que trucidam membros do Partido Comunista do Brasil, sob comando do delegado Sérgio Paranhos Fleury.
} 
tapete artesanal de Diamantina/MG, sua terra natal - e escultura de JK realizada por Honório Peçanha com 4,5 m de altura, a 30 metros da base.

Entre domesticidade e vida pública, na parte externa residem mais obras: o casal em banco de jardim em bronza de Roberto Sá, sete esferas de aço do artista Darlan Rosa, incluídas no centenário de JK (2002), e um Ford Galáxie 1974. No interior, estão jóias, rosário, trajes, junto a fotos, placas, comendas, documentos, presentes, souvenir e peças, a ilustrar ênfases de seu Governo, como a primeira máquina de somar feita no país e doada a ele em 1958.

A parte civil do casal se instalou no térreo composta por Biblioteca com obra completa de Willian Shakespeare doada pela Rainha da Inglaterra e o Gabinete da viúva, espécie de casa-museu em memorial. No andar superior, o túmulo em tronco de pirâmide sobre base circular, irradia-se de forma pungente. Convive com objetos pessoais, história local e nacional. Assim trabalha-se com aquilo que Assmann denomina lugares traumáticos (2011, p. 35).

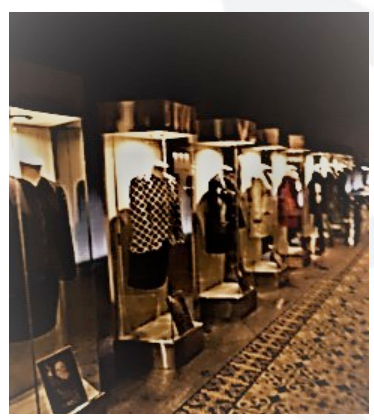

Figura 5. Memorial JK. Interior com vestuário. Brasília/DF. Foto A. 19.4.2019

Função, subsídios ao coletivo e, mesmo procura em escancarar discriminação requerem estratégias para se enraizar, a iniciar pela seleção de coleção e local a ser implantado. O Memorial JK traduz o relevo desses fatores: Dona Sarah desativara a casa no Rio de Janeiro com o fito de ofertar peças para compô-lo. Contudo, disparou-se uma série de entraves, desde a doação de terreno e 
localização aspirada, a saber, o Eixo Monumental ${ }^{12}$. Além disso, disputava-se local simbólico, onde se efetuara a Primeira Missa em Brasília (1957.

Vetos recaíram também em Niemeyer, com falas pueris, a incluir a obra no alto de JK. No dizer do professor, scholar, arquiteto e historiador Júlio Roberto Katinsky, a escultura do ex-presidente fôra proposta para fricção contra o céu de Brasília. Todavia opuseram-se á solução da peça no fuste, em frente ao Memorial. Alegava-se que ele "[...] desenhara uma foice e que o braço de Juscelino Kubitschek seria o martelo do emblema comunista [...] (1990, p. 54)".

Outra criação de Niemeyer, a causar sonhos e pesadelos, deu-se no hoje nomeado Memorial dos Povos Indígenas/MPI. Ao ser acabado, o então governador do DF, José Aparecido de Oliveira, em fala infeliz, avaliou ser muito bonito para a destinação. Aberto como Museu de Arte Moderna, em 1990, expôs o venezuelano Armando Reverón. Em 1992, com Fernando Collor de Mello, este decidiu que iria alterar para o de Arte Contemporânea, com peças de arte dispersas em órgãos federais, sem sucesso.

Dois anos depois (1994), foi reaberto como extensão do Instituto Histórico e Geográfico, mas, de breve duração (3 meses). Em 19 de abril de 1995, no Dia do Índio, membros das tribos Karajá, Kuikuro, Terena e Xavante oficiaram rito por reaver o espaço. Protestos ocorriam e, a cada nova ameaça, esforços para reabri-lo, com realce ao empenho no governo de Cristóvam Buarque no DF.

\footnotetext{
${ }^{12}$ Eixo Monumental marca a parte central do Plano Piloto e conta com sítios de relevo: Praça dos Três Poderes, Esplanada dos Ministérios, Catedral, Câmaras, Palácio do Itamaraty.
} 


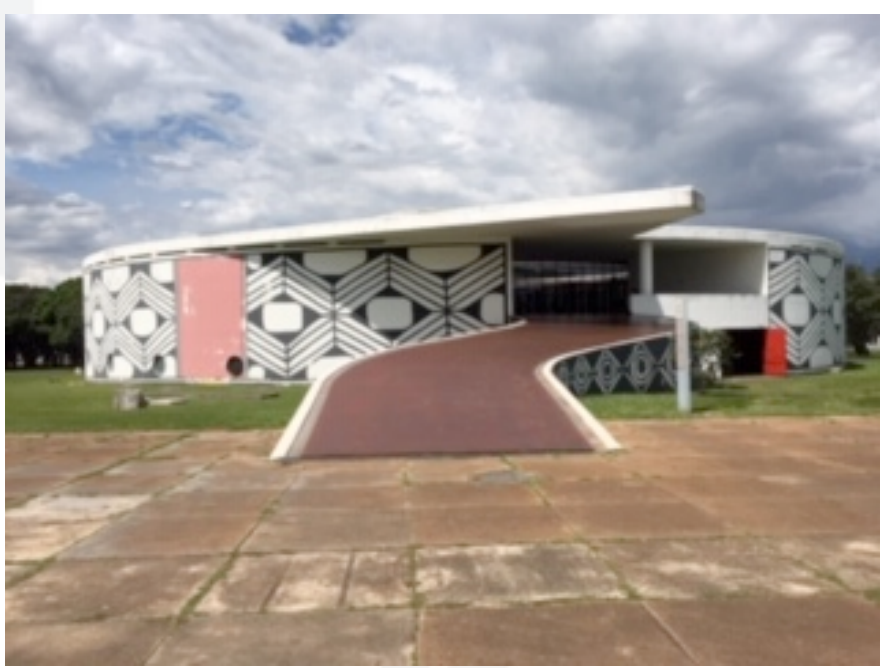

Figura 6. Oscar Niemeyer. Memorial dos Povos Insígenas. Brasília/DF. Foto A. 19.4.2019

Em que pesem variadas diligências, esteve fechado até $1999^{13}$; mas, pela ação de etnias, apoiadores e profissionais, de tempos em tempos captam-se novos influxos sob a égide de repaginá-lo para expor a coleção. Entre as ações, em 2015, índios Yawalapiti realizaram durante um mês pintura do grafismo original do Xingu na parede externa do memorial. A idéia então difundida seria de rodízio entre os grupos, mas ainda se mantêm até a data de visita (2019).

A coleção salvaguardada no MPI institui cultura distinta, pois, proveio de antropólogos e estudiosos, entre estes, Darcy Ribeiro e sua primeira mulher, Berta, Eduardo Galvão e irmãos Villas Boas - Orlando, Cláudio e Leonardo. Possui forma circular em concreto armado com 70 metros de diâmetro. No centro há vazio acolhedor, em parte coberto e com salas abrindo para este e ensejando conforto térmico e muita luz.

\footnotetext{
${ }^{13}$ Como se informou (1997), o MPI foi aberto para rituais de luto ante a violência contra o índio Galdino dos Santos, que fora ao DF para reivindicar direitos no Dia do Índio, sendo queimado.
} 


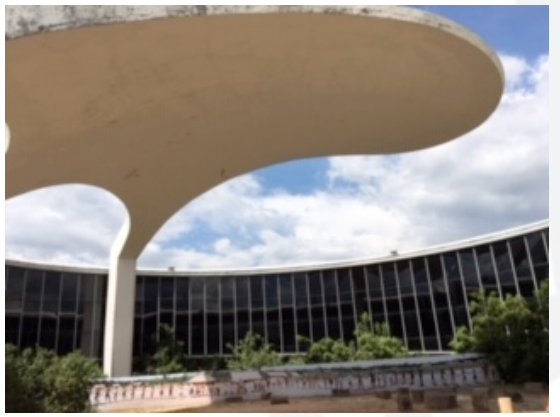

Figura 7. Arq. Oscar Niemeyer. Interior do MIP. Brasília/DF. Foto A. 19.4.2019

Larga rampa conduz público do térreo ao andar principal. Sutilezas foram propostas, desde o ingresso do visitante: enquanto neste sai-se da intensa luz da rua para certa penumbra, em outros, como o de JK e o de Prestes, aclive leva à entrada e acentua desenho magno adotado no edifício, a espiral. Neste caso, Niemeyer preferiu a forma de maloca dos índios Yanomami.

Negados, ou mesmo, pouco apoiados pelo Estado, realizam-se iniciativas notáveis, por meio de palavra, texto, sons, dança, ato político, literatura, poesia, teatro, imagem, artes visuais, livros, fotos, gravação, arquivos, mostras, eventos, debate crítico com variado público. Ao promover registros, testemunhos, contação de história, oficinas, obras desafiam falas que, ao contrário, buscam desqualificar partes do passado, pois, reavivam ou expõem fronteiras borradas entre lembranças assentadas.

Condição essencial para se consolidar marco decorre também de repetição em ações abalizadas, celebração em ritos, implantação em área próxima à passagem habitual e revisão de poéticas, ficando o contrário afetado. Optamse até mesmo por recursos de extrema comoção, entre as quais trasladar corpos e ritual fúnebre, para impregnar espaços com ares de sacralidade, além de conteúdos atinentes ao que se deseja registrar como apropriado.

Personalidades ativistas em causas de segmentos postos à margem igualmente provocam reações. Observe-se, no Distrito Federal, o Memorial Darcy Ribeiro, que documenta viragens históricas após alternância de forças: de um lado, em 
1996, antigas lidas do antropólogo se concretizaram: recebera o título de Doutor Honoris Causa e seu nome fôra dado ao campus da UnB.

Com saúde abalada, Ribeiro pediu a Lelé, seu colega, atuante no início da UnB, para que projetasse uma edificação visando abrigar coleção sua e de Berta, em que coligaram conjunto de época e edições abissais para várias áreas. Como se alude no site da Fundação, o antropólogo à época afirmou algo central neste estudo: "[...] como o sonho de uma geração se tornava, nos tempos da ditadura, um amargo pesadelo". De imediato, a reitoria cedeu espaço, congregando biblioteca, cúpula que também age como climatizador.

Espaço para descanso no térreo, por Ribeiro batizado por Beijódromo, como também é conhecido o edifício, sempre referido em mistura de disco voador e oca indígena. No andar superior reside a notável Biblioteca, com acervo fundamental, estando à disposição da comunidade da UnB. A exposição As utopias de Darcy dialoga com o acervo ao aliar livros, documentos, arquivo, peças indígenas, fotos e obras de arte ${ }^{14}$.

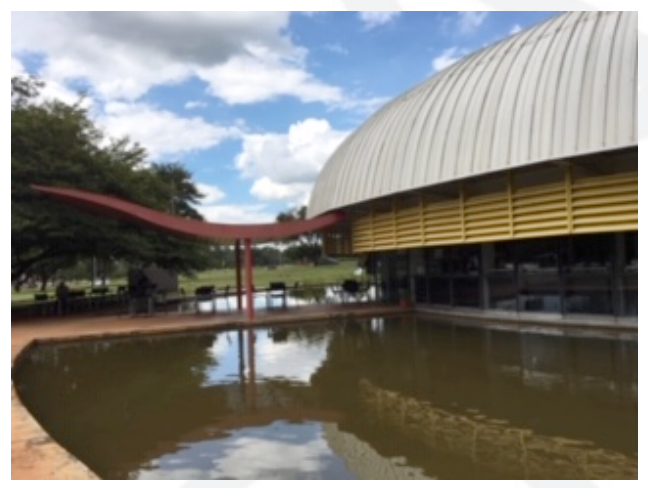

Figuras 8. Arq. Joaquim Filgueira. Memorial Darcy Ribeiro. Brasília/ DF. Foto em 02.05.2019

${ }^{14}$ Isa Grispum Ferraz selecionou conjunto para a mostra que decorre de longa parceria entre Ribeiro e a curadora, estudiosa, documentarista, roteirista e voltada a ações educacionais, sendo o projeto do arquiteto Marcelo Ferraz.Também cuidou da série feita por GNT e TV Cultura, com base em $O$ povo brasileiro do antropólogo. 
Intersecção entre museu, história, memória e valorização de identidades se encontra no Museu Vivo da Memória Candanga, de Brasília/DF. Situado no Núcleo Bandeirantes/DF, às margens de rodovia, com acesso difícil para pedestres, instalado, após os conflitos no MIP. Antes, no local sediou o primeiro hospital e abrigou obreiros. Exibe fazeres, utensílios e fotos da construção da capital, tendo sido o espaço adaptado pelos arquitetos do Departamento de Patrimônio Histórico e Artístico Nacional/DF Silvio Cavalcante, Antônio Menezes Júnior e Carlos Madson Reis.

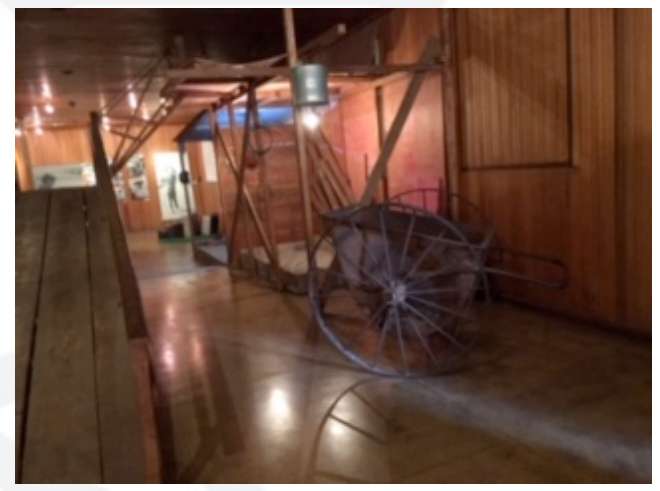

Figura 9. Museu Vivo da Memória Candanga, Núcleo Bandeirantes. Brasília/DF. Foto A. em 17.04.2019

\section{Luto: quadro a quadro}

Memoráveis permanecem, na medida em que seus feitos representam exemplo, valor, singularidade. Reinhart Koselleck $(2014$, p.63)

Museu e Memorial aproximam-se também no afã de negar servidão e saudar a liberdade, em diálogo com instituições nacionais na tipologia Museu Histórico. Como afirma Assmann, o despontar deste, formula referencial para os demais ligados a acolher, documentar, exibir, conservar e propor conhecimento. Assmann, como também indicara Michel Foucault ${ }^{15}$, reafirma o intento em

\footnotetext{
${ }^{15}$ Ao se referir a gabinete e jardim na chamada idade clássica Foucault, em As palavras e as coisas (1966), assegura que estes reorganizaram “[...] o desfile circular do 'mostruário' pela exposição das coisas em 'quadro' [...]” (1992, p. 145).
} 
conceber uma unidade na História Nacional, quadro a quadro (2011, p. 52), permeados por fatos para internalizá-la via comoção.

Nessa direção, cabe grifar que, em paralelo à etapa em que globalização de economias e mundialização cultural primam na cena internacional memoriais com mote local, regional e nacional ${ }^{16}$. A aposição acena para intento de povos e grupos em se firmar, para não se ofuscar identidades, tragadas pelos negócios, colonialismo, mercado e modos vindos de capitalismo central, não raro centrado em espetáculos e discursos grandiosos.

No entanto, nesta época retrô sobram revivalismos e transposições, mesmo na criação. No último estudo Reinhart Koselleck afirma que repetições se dão mesmo nas "[...] artes, por mais originais que possam ser, possibilidades preexistentes. Toda recepção contém ou revela repetições" (2014, p. 13-4). Ainda assim, novas obras ímpares vêm sendo erigidas, a apontar passado trágico, neste século e após a Queda do Muro de Berlim.

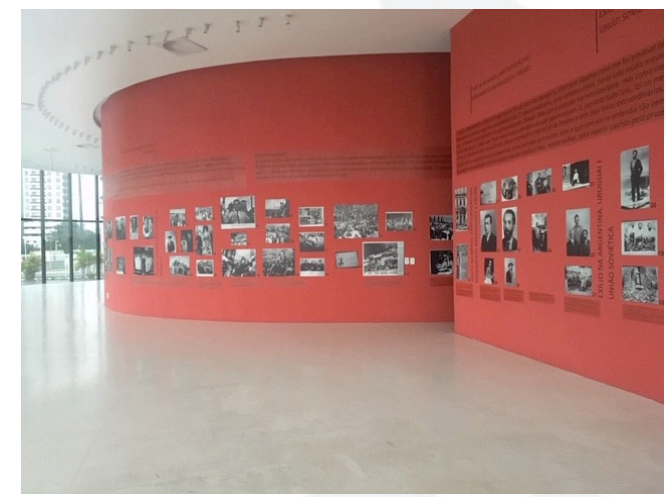

Figura 10. Arq. Oscar Niemeyer. Memorial Luís Carlos Prestes. Porto Alegre/RS. Vista dos módulos, desde o exterior. Foto A. 31.05.19

Túmulos e memoriais também dialogam ao suscitar emoção, acolher rastros materiais e em tentar manter viva a memória, ou mesmo o corpo da

${ }^{16}$ Como lista a Unesco há muitas inscrições como Patrimônio Mundial, entre 2000-3 de túmulos chineses a: em 2000: Xianling (Zhongxiang); Dinastia Qing (Zunhua); Dinastia Qing (Baoding); Ming (Pequim); Xiaoling (Nanjing); Chang Yuchun (Nanjing); Qiu Cheng (Nanjing); Wu Liang (Nanjing); em 2003: Wu Zhen (Nanjing); Xu Da (Nanjing); Li Wenzhong (Nanjing). 
autoridade $^{17}$, pela simples deposição no local ou mumificação. Desde a cultura egípcia aprimorou-se tal meio, lembrando a Tumba de Tutankamon que governou entre c. 1332-1323 a.C. Assim, museu histórico e memorial resvalam na busca em conservar, (re)construir todo coeso com formas laudatórias, a exaltar território ou personagem e sua riqueza material, sem desnudar aspectos críticos ou conflito evidente, como se não existissem.

A sacralidade a exigir reverência se nota quando aludem a mortos em conflito, a citar o de Ermesto Che Guevara, que esclarece o que Assmann designa por memórias revolucionárias. Visa balizar o devir para jóvens, em luta e dedicação ao país, até a morte. Por outro lado, minimizam-se tanto o esconderijo quanto a forma em que foi morto o argentino-cubano. Polêmicas se deram, ao não se saber o destino dos restos mortais, mas se construiu memorial em local de uma das batalhas por ele dirigida em Santa Clara/Cuba (1988).

Che morrera na Bolívia e esteve enterrado em local secreto. 0 pacto rompeuse quando Jon Lee Anderson, autor de Che Guevara: A Revolutionary Life, obteve o informe, ao inquerirr oficial boliviano. Após escavações, acharam os restos mortais, junto com o de outros, (1997). Na parte central do memorial, está o túmulo iluminado por feixe de luz e a visita seguida pela guarda cubana, a ordenar decôro: proibido tirar fotos, entrar com boné ou chapéu, bolsa, mochila, sacola ou guarda-chuva e exigem silêncio. Crianças apenas brincam na escadaria externa.

\footnotetext{
${ }^{17}$ Veja-se que, entre obras em exame nesta pesquisa, o de Kubitschek contém no andar superior, em local central, o corpo trasladado para abertura (1982). Dias antes, fora exumado, velado na Câmara e, levado em séquito, desta, à cripta. Recebeu honras de Estado, por ironia, saudou-o com salva de tiros, as "[...] três armas nacionais - Marinha, Exército e Aeronáutica - em uniforme de gala, prestaram-lhe homenagens à entrada do Memorial".
} 


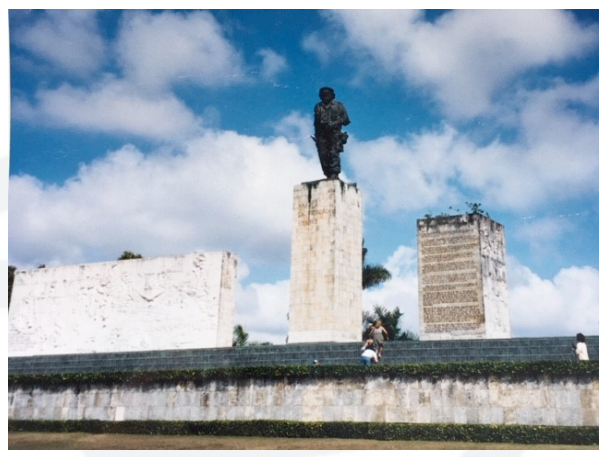

Figura 11. Arq. Jorge Cao Campos e escultor José de Lázro Bencomo, Memorial Comandante Che Guevara (1988). Santa Clara/Cuba. Foto A. 15.01.2004

Agregram-se há muito conjuntos mortuários inolvidáveis, esplendorosos, monumentais, singulares e polêmicos e, na época presente, vários registrados - Patrimônio da Humanidade -, pela Unesco. Mantêm obras e/ou figuras ditas incomuns, logo, dignas de honrarias. Não importa à fruição fatores como condições restritas de acesso ou vazio interno mínimo, como nas Pirâmides egípcias. Vale experienciar lado humano inolvidável, por criação, engenho técnico, construtivo e a emoção ao se defrontar com anos históricos.

A prática de tesouros, a garantir vida post mortem ocorreu em monumentos de várias religiões, como morada provisória, ante a promessa de retorno ao convívio, de fiéis às normas. Depositavam objetos em material disputado, como jóias, além de servos representados ou até vivos, como reza a tradição. A presença de peças de valor venal causou todo tipo de agravo, ainda que garantindo mistério sobre exato local e, não raro, sofreram pilhagem e desonra por sucessores. Ainda com esse passado, memoriais e túmulos continuam a ser erigidos, com aparato precioso no interior.

No tocante a se camuflar o sítio exato, o conjunto arqueológico em Xian província de Shaanki/China bem documenta: descoberto apenas em 1974, tãosó parte está visível, embora sejam muitos e em escala natural. Reúnem guerreiros, armas, carruagens e cavalos, a maioria em terracota. Seguem escavações, sendo que para alguns precederiam o Mausoleu do primeiro Imperador da dinastia Qin - Shi Huang Di (Século III a.C.). Se este fôra 
protegido em vida, então, tal exército garantiria a após a morte. A distância destes à tumba lança outras teorias, alertadas no lugar. Curiosa é a diferença entre feições, traje, adereços e altura, esta talvez pela hierarquia militar.

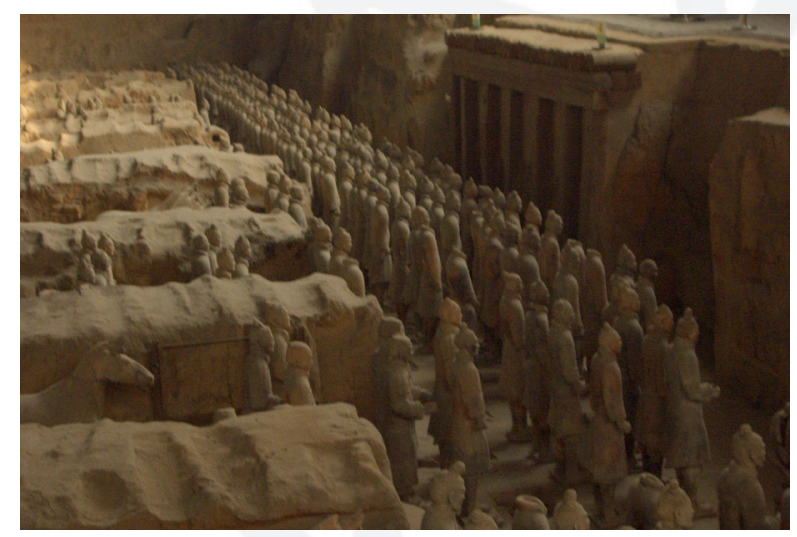

Figura 12. Parte escavada de "Guerreiros" em terracota. Xian/China. Foto A. 31. 01.2008

\section{Morte e indagação}

Nos memoriais dos campos de concentração vemos de forma clara o que também vale na Alemanha, após a Segunda Guerra Mundial, para os memoriais dos mortos: a morte não é mais vista como resposta, mas apenas como pergunta [...]. Reinhart Koselleck (2014, p. 258)

Koselleck em seu último estudo, reafirma que memoriais não constituem resposta, ao contrário, exigem interrogações para se rever o passado ante o tempo presente. Formulam-se em Considerações Finais algumas demandas para estimular outras, por considerar que Memoriais podem disseminar conjunto notável para revolver histórias escamoteadas.

Narrativas após amorte emanam de amigos e da própria família, desta maneira, para Koselleck relatos possuem entre seus atributos situar-se no limite entre lendas, mitos "[...] e os contos de fadas, de um lado, e o anseio por notícias confiáveis, de outro. Aqueles se escondem em algum lugar na escuridão do passado, essas são iluminadas pela luz da tradição verificável” (2014, p. 266). 
Memória manifesta-se igualmente em lugares traumáticos (Assmann, 2011, p. 351) a clamar por se expurgar destes sítios ações vazadas por lesahumanidade, na busca de evitar esquecimento ativo ${ }^{18}$, para juventude. Ou acompanhando Assmann: "O que se seleciona para recordação sempre está delineado por contornos de esquecimento" (2011, p. 437).

Entre nós, as memórias traumáticas adiaram a ser criadas, por esquecimento ativo ou passivo, par proposto por Jean-Louis Déotte. Surgiram placas, marcas, antimonumento e, igualmente, edifícios foram Tombados ${ }^{19}$. Em especial aqueles em que funcionaram órgãos como Departamento de Ordem Política e Social/Dops, Centro Clandestino de Detenção/CCD. Emergem do pretenso apagamento segundo Assmann definiu por memória involuntária, a que "[...] traz à luz uma descoberta tardia repentina" (2011, p. 358).

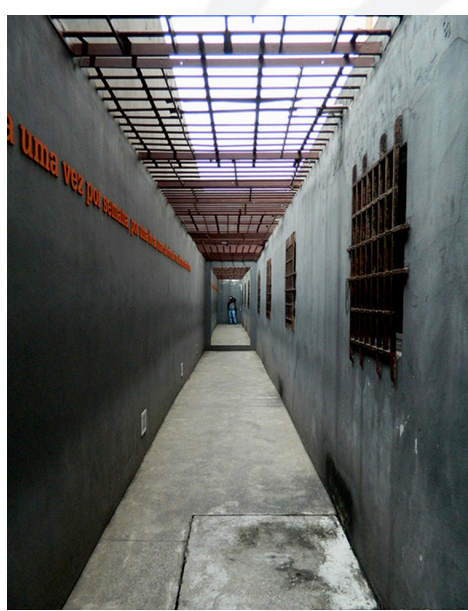

Figura 43. Memorial da Resistência. São Paulo/SP. Exposição A construção da memória: o cotidiano nas celas do Deops/SP. Foto A. 1.11.2013

${ }^{18}$ Como afirma Jean-Louis Déotte, na esfera museica sobre o que denomina oubli actif $x$ passif "[...] procede necessariamente ao esquecimento de determinadas identidades étnicas e históricas. Institui o esquecimento ativo. Suspende as destinações" (1994, p. 26).

${ }^{19}$ Cito entre os locais de violência estatal: 1993 - Prefeita Luiza Erundina inaugurou memorial no Cemitério Dom Bosco, Perus/SP, em que depositaram, em valas, presos políticos. 2002 - Estádio Vila Euclides, em que chacinaram trabalhadores ali reunidos, São Bernardo do Campo/SP. 2004 Presídio em Porto Alegre e Guaíba, na Ilha das Pedras Brancas/RS. 2016 - Dops/ BHMG. 2014 Órgão de Operações de Informações e do Centro de Operações de Defesa Interna (OBAN - DOICodi) II Exército SP/SP, sede da "Operação Bandeirantes". 2018 - CCD, tido como "Casa da Morte", em que ativistas sumiram, Petrópolis/RJ. 
Em variadas ocasiões no país tentou-se abafar o que de fato sucedeu, mas vozes de vítimas vêm sendo amplificadas contra algozes, até blindados pelo Governo $^{20}$. $\mathrm{O}$ caso paulista documenta esses ritos e conflitos: o ativo Sindicato dos Jornalistas propôs tombamento do prédio em que funcionou órgão repressivo, o Departamento Estadual de Ordem Política e Social/Deopes, na capital. Seguido o trâmite, exarou-se parecer como bem cultural.

Razões para o Ato de Tombamento ${ }^{21}$ registraram tópicos acessórios, enaltecendo-se o relevo para memória social paulista, realçando-se atributos materiais, técnicos, projetuais, estilístico e autorais, pois, fôra da lavra de Francisco de Paula Ramos de Azevedo, festejado arquiteto local. Oposta e expressiva solução ocorreu ao se implantar Memorial da Resistência em $2008^{22}$, a desvelar condições lúgubres impostas a cidadãos ativistas.

\section{CONSIDERAÇÕES FINAIS}

Memoriais ligados à morte de personagem reconhecido pelo Estado trabalham com momentos de brilho e raridade, mas podem desafiar o estabelecido. Cabe ressaltar que a consecução de ritos fúnebres assume diferentes formas culturais, unindo-as o impacto da morte, luto e simbologias. Visam a honrar a vida ou indicar caminho desejado aos que ficam, por vezes assumindo caráter de sacralidade, tendo ideologia e distintas religiões, como fatores de relevo para ser cultuado e, mesmo, venerado. Cumprem tais propósitos?

\footnotetext{
${ }^{20}$ Vale lembrar que Jair Bolsonaro, então deputado, ao declarar voto em apoio à abertura de processo para impedimento da então Presidenta Dilma Rousseff (2016) saudou Carlos Alberto Brilhante Ustra, reconhecido como torturador por vítimas e pela Justiça, em sentença do juiz Gustavo Santini Teodoro, da 23. a Vara Cível (2008), reiterada em 2012 e veiculada por diversas mídias. Ustra chefiou do DOI-Codi do Exército/SP, local em que cerca de 500 desapareceram e 50 faleceram, segundo Relatório CVN e posto em dúvida pelo atual presidente (30.7.19).

${ }^{21}$ Resolução $n^{\circ} 28$ (1999) firma as razões: abrigar vários usos: armazém para Estrada de Ferro Sorocabana, Arquivo do Estado e Deops, sem aludir às mazelas, talvez por conflitos internos.

${ }^{22}$ O Projeto de Ocupação ocorreu na Pinacoteca, gestão de Marcelo Araújo, a cargo Maria Cristina Bruno, Maria Luiza Carneiro, Gabriela Aidar. Projeto Museológico (2010) foi elaborada por Bruno e Beatriz de Arruda, Francisca Aida Figols. Dados do Site do Memorial.
} 
Mito, lenda, ideologia, pavor, devoção e reação misturam-se e unem dada identidade, por vezes, ameaçada por quadro distinto, como agora no país. Quando se tenta sufocar episódios, o que esperar de prestígio aos memoriais, a abrigar alteridade? Como se viu, Memorial há muito compõe-se por formas, imagens, textos e sempre aborda a morte efetiva ou provável, de causas, etnias e pessoas, em especial, quando se tenta espoliar subsídios no passado ao coletivo, ou mesmo, rever atrocidades contra certos segmentos.

Memoriais desde os Anos 1980 com sutileza inquirem várias questões latentes, aqui explanadas: o porquê de apagamento em lutas; qual o sentido de abater a diferença com a morte? Esse crime lesa humanidade merece ser anistiado? 0 porquê da extensão por 21 anos de interferência militar? Seria crível o pleno retorno à democracia? Cessaria a suspenção de Atos monocráticos discricionários com ideais distintos? Seria quimera a volta dos militares às funções precípuas nos quartéis, fazendo-se justiça aos responsáveis diretos? Olvido programático fundamentaria memoriais?

Questiona-se: Quando e por que políticos são alvo de Memorial? Quais e por que alguns obtiveram projeto de Oscar Niemeyer? Quais as perguntas decisivas a envolver os sentidos submersos? Como se dá o luto, desde iniciativas de Estado, a configurar mea culpa? Que imaginário, ícones, signos, símbolos, significados do corpo sacrificado são utilizados? Como operam lembranças concorrentes e memórias traumáticas em memoriais? Ao negar truculência, conferem veracidade e apaziguam algozes ou apenas afrontam memórias?

Fica aqui o apelo para diálogos sobre lutas, resistências, função política, memorialística, artística, expositiva, valor propositivo e, sublinho, crítico, no trato com questões públicas. Fatos e processos culturais contribuem para revolver e, mesmo, tentar eternizar histórias prestes a se desfazer. No entato às novas gerações não se pode negar o vivido, diretamente imbricado com suas certezas, dúvidas, sonhos, pesadelos e luto. Ciça, inverno 2019. 


\section{BIBLIOGRAFIA CITADA}

Assmann, Aleida. Espaços da recordação: formas e transformações da memória cultural. Campinas: Ed. Unicamp; 2011.

Déotte Jean-Louis. Oubliez! Les ruines, l'Europe, le Musé. Paris: Harmattan; 1994.

Foucault M. As palavras e as coisas. 6a ed. São Paulo; Martins Fontes, 1992.

Katinsky, Júlio Roberto. Brasília em três tempos: a arquitetura de Oscar Niemeyer na capital. Rio de Janeiro: Revan; 1991.

Koselleck Reinhart. Estratos do tempo: estudos sobre história. 1a ed. Tradução Markus Hediger. Rio de Janeiro: Contraponto/PUC-Rio; 2014.

Ricoeur Paul. A memória, a história, o esquecimento. Campinas: Ed. Unicamp; 2007.

\section{Fontes eletrônicas e sites}

Comissão da Verdade da Câmara - Juscelino Kubitschek Rede Brasil Atual, 25 nov. 2015 [citado 24 jul. 2019]. Disponível em: https://www.redebrasilatual.com.br > Cidadania

Comissão da Verdade - tortura. Texto de Tatiana Santiago em 14.8.12. [Citado 29 jun. 2019]. Disponível em: https://veja.abril.com.br/brasil/justicamantem-decisao-que-reconhece-coronel-ustra-como-torturador/

Comissão da Verdade do Estado de São Pauulo. "Rubens Paiva". Recomendações Gerais e Recomendações Temáticas Tomo I. [Citado 24 jul. 2019]. Disponível em:

http://comissaodaverdade.al.sp.gov.br/arquivos?q=Morte+de+juscelino +kubitschek/

Comissão da Verdade do Estado de São Pauulo. 'Rubens Paiva' - Juscelino Kubitschek. Tomo IV. 11.12.2014. [Citado 24 jul. 2019]. Disponível em: http://comissaodaverdade.al.sp.gov.br/relatorio/tomoiv/downloads/IV_Tomo I pdf

Decreto de Tombamento do Dops/ SP. [Citado 23 mai. 2019]. Disponível em: https://www.prefeitura.sp.gov.br/cidade/upload/.pdf.

Inaugurações do Museu dos Povos Indígenas. [Citado 14 ago. 2019]. Disponível em: https://seculosindigenasnobrasil.files.wordpress.com/2010/07/hist_m em_povos_indig1.pdf

Índios preparam atos contra a morte de Pataxó. O Estado de S. Paulo 22.4.1997, Caderno Cidade, p. 1. [Citado 11 ago. 2019]. Disponível em: https://documentacao.socioambiental.org/noticias/anexo_noticia//30 459_20150401_143047/ 
Mausoléus inscritos na lista do Património Mundial da Unesco em 1988.

[Citado 19 mar. 2019]. Disponível em:

https://news.un.org/pt/story/2013/01/1427411-unesco-revela-

intencao-de-ajudar-reconstruir-patrimonio-cultural-do-mali/.

Memorial JK. [Citado 21 mar. 2019]. Disponível em:

http://www.memorialjk.com.br/pt/

Memorial dos Povos Índígenas. [Citado 11 ago. 2019]. Disponível em: https://trabalhoindigenista.org.br/category/memorial-dos-povosindigenas/

Memorial dos Povos Índígenas: 314 etnias. [Citado 11 ago. 2019]. Disponível em:https://gpslifetime.com.br/conteudo/entretenimento/arte/80/mem orial-dos-povos-indigenas-local-representa-314-etnias-do-pais?page=8/

Memorial da Resistência. [Citado 15 ago. 2019]. Disponível em: http://www. memorialdaresistencia.sp.org.br/memorial/

Site Unesco. [Citado 28 jul. 2019]. Disponível em http://whc.unesco.org/fr/list/arb/

Situação atual da Transamazônica. [Citado 15 ago. 2019]. Disponível em: https:// faunanewa. com.br/artigo/2917/07fauna-e-estradas transamazonica-causa impacto/ 